\title{
A comparative analysis of precision seed planters
}

\author{
Noureldin Sharaby ${ }^{1,2,{ }^{*}}$, Artyom Doroshenko ${ }^{1}$, Andrey Butovchenko ${ }^{1}$, and Aleksandr \\ Legkonogih $^{1}$ \\ ${ }^{1}$ Don State Technical University, 344000 Rostov-on-Don, Russian Federation \\ ${ }^{2}$ Agricultural Engineering Department, Faculty of Agriculture, Kafrelsheikh University, Egypt
}

\begin{abstract}
Crops play a vital role in our daily life, as they represent the backbone of all life on earth and an essential resource for human food, feed grain, oil, and fiber for local consumption and a major component of export trade in many countries, leading to its increasing demand all over the world. Precision planting is the effective method to rise crop yield. To meet the agricultural requirement of precision planting, various types of different precision seed planters have been developed. However, because of the difference of farm scale, geographical environment, crop type and economic status among different countries, types of seed planters are various, and the technique involved are at different levels. This paper analysis and compare of some typically precision seed planters currently available in the world. Detailed characteristics have been provided for some typical precision planters and comparisons were made as to their suitability under working conditions. This allows the smallholder farmers to assess and select the appropriate precision seed planter that corresponds to the potential and characteristics required, for example, planting seeds, the possibility of adding fertilizer during cropping, the number of rows and the horsepower required, controlling the seeds rate, spacing between seeds in the same rows in addition to more other options.
\end{abstract}

\section{Introduction}

Agronomic crops have a variety uses as food, industry, chemical and medicine with its ever-increasing demands in recent years. Cereal crops output is of strategic significance to ensure food security and increase peasantry income. For example, global consumption of cereals crops is projected to increase from 2.6 bln $t$ in 2018 to 2.9 bln $t$ in 2027, driven mainly by higher feed use $(+167 \mathrm{Mt})$ followed by food use $(+151 \mathrm{Mt})$. Developing countries will account for $84 \%$ of the projected increase in overall consumption according to the data of FAO. Demand for crops consumption will continue to expand because of population growth and higher per capita income for most commodities. As the composition of per capita consumption of cereals in the Middle East and North Africa is the highest compared with other regions around the world [1]. There are a lot of factors

\footnotetext{
${ }^{*}$ Corresponding author: Noureldin_Sharaby@agr.kfs.edu.eg
} 
affecting crops yield [2] and precision planting technology is considered as one of the most important factors.

Precision sowing is the best method between different sowing techniques compared with other methods. Precision planting can bedefinedas it is used for accurately place single seeds or groups of seed almost equidistant apart along a furrow. Precision planters are typically used to plant crops that require accurate control of plant population, specific spacing between and along the rows, in contrast to the ones planted through grain drills. They use a different form of metering mechanism. Row crop planters are generally used to plant large seeds; however, they're also used to plant small-seeded. The common metering units for row crop planters are known as plate, disk, and drum. A common feature of these kinds of metering units is modification the planting rate via changing the velocity, within limits, using a mechanical drive wheel, hydraulic or electric drive motor controlled using computer.

In general, precision planter consists of soil and residue cutting device, fertilizer unit, row preparation device, furrow opener, depth control unit, seed meter unit, power transmission system, seed firming devices, seed covering devices and row specific seedbed firming devices. However, the actual structure and working principle of precision seed planters are various because of the difference of geographical environment, crop type, farm scale, climate condition among different countries around the world. For tilled land with flat surface and appropriate planting condition, high-efficiency and high-speed precision planters are usually applied, while there are high levels of plant residue on the soil surface, the cutting device is used, but when the seedbeds are unprepared, row preparation devices may be required in addition to the furrow opener.

This paper presents a comparison of some different types of precision seed planters with different models in different parts of the world which they are currently used to plant different types of seeds. There is a difference in the number of rows and distance between rows, Consequently, there are a variation in the working width from one precision seeds planter to another and from one model to another (Table1) precision planters are available for tilled and no tilled land.

Table1.Comparison of different kinds of precision seed planter models in terms of spacing between rows, working width, rows numbers and type of seedsplanted via these models

\begin{tabular}{|c|c|c|c|c|c|c|}
\hline Machine name & Models & Row numbers & $\begin{array}{c}\text { Rows } \\
\text { Spacing, } \\
\text { cm }\end{array}$ & $\begin{array}{c}\text { Working } \\
\text { width, } \\
\text { m }\end{array}$ & Type of seeds & $\begin{array}{l}\text { Manufacturing } \\
\text { Countries }\end{array}$ \\
\hline \multirow[b]{2}{*}{$\begin{array}{c}\text { KvernelandMonopil } \\
\text { l }\end{array}$} & Monopill rigid & $\begin{array}{l}6 / 12 / \\
18 / 24\end{array}$ & $45 / 50$ & $3 / 6 / 9 / 12$ & \multirow[b]{2}{*}{$\begin{array}{l}\text { Beet, rape } \\
\text { and chicory }\end{array}$} & \multirow{6}{*}{$\begin{array}{c}\text { Norway, } \\
\text { Denmark, } \\
\text { Germany, The } \\
\text { Netherlands, } \\
\text { France, Italy, } \\
\text { Russia and China }\end{array}$} \\
\hline & $\begin{array}{l}\text { Monopill } \\
\text { hydraulic } \\
\text { folding }\end{array}$ & $12 / 18$ & $45 / 50$ & $6 / 9$ & & \\
\hline \multirow{4}{*}{$\begin{array}{l}\text { Kverneland } \\
\text { Optima }\end{array}$} & Optima rigid & $\begin{array}{c}6 / 8 / \\
12 / 18\end{array}$ & $60 / 50$ & $\begin{array}{l}3 / 4.5 / \\
6.1 / 9.3\end{array}$ & \multirow{4}{*}{$\begin{array}{c}\text { Maize, } \\
\text { sunflowers, } \\
\text { Beans, } \\
\text { beets, etc. }\end{array}$} & \\
\hline & $\begin{array}{l}\text { Optima } \\
\text { hydraulic } \\
\text { folding }\end{array}$ & 12 & 50 & 6 & & \\
\hline & $\begin{array}{l}\text { Optima TF } \\
\text { profi }\end{array}$ & 8 & $70 / 75 / 80$ & 6.2 & & \\
\hline & $\begin{array}{l}\text { optima TF } \\
\text { maxi }\end{array}$ & 16 & $70 / 80$ & 12 & & \\
\hline \multirow{3}{*}{ Horsch } & Maestro CC & $6 / 8 / 12$ & $\begin{array}{c}70 / 75 / \\
80 / 45 / 50\end{array}$ & $4.4 / 6 / 5.7$ & \multirow{3}{*}{$\begin{array}{l}\text { Maize, } \\
\text { sunflowers, } \\
\text { sugar } \\
\text { sorghum, soy } \\
\text { beans, beet, } \\
\text { rape and } \\
\text { cotton }\end{array}$} & \multirow{3}{*}{$\begin{array}{l}\text { Germany, USA, } \\
\text { United Kingdom, } \\
\text { France, Russia, } \\
\text { Ukraine, Brazil, } \\
\text { Czech Republic } \\
\text { and China. }\end{array}$} \\
\hline & Maestro RC & $8 / 12$ & $\begin{array}{c}70 / 75 / \\
80 / 45 / 50\end{array}$ & $6 / 5.7$ & & \\
\hline & Maestro SW & $12 / 16 / 18 / 24$ & $\begin{array}{l}70 / 75 / \\
45 / 50\end{array}$ & $\begin{array}{l}9.6 / 12 / 8.6 / \\
11.4 / 17.4\end{array}$ & & \\
\hline
\end{tabular}




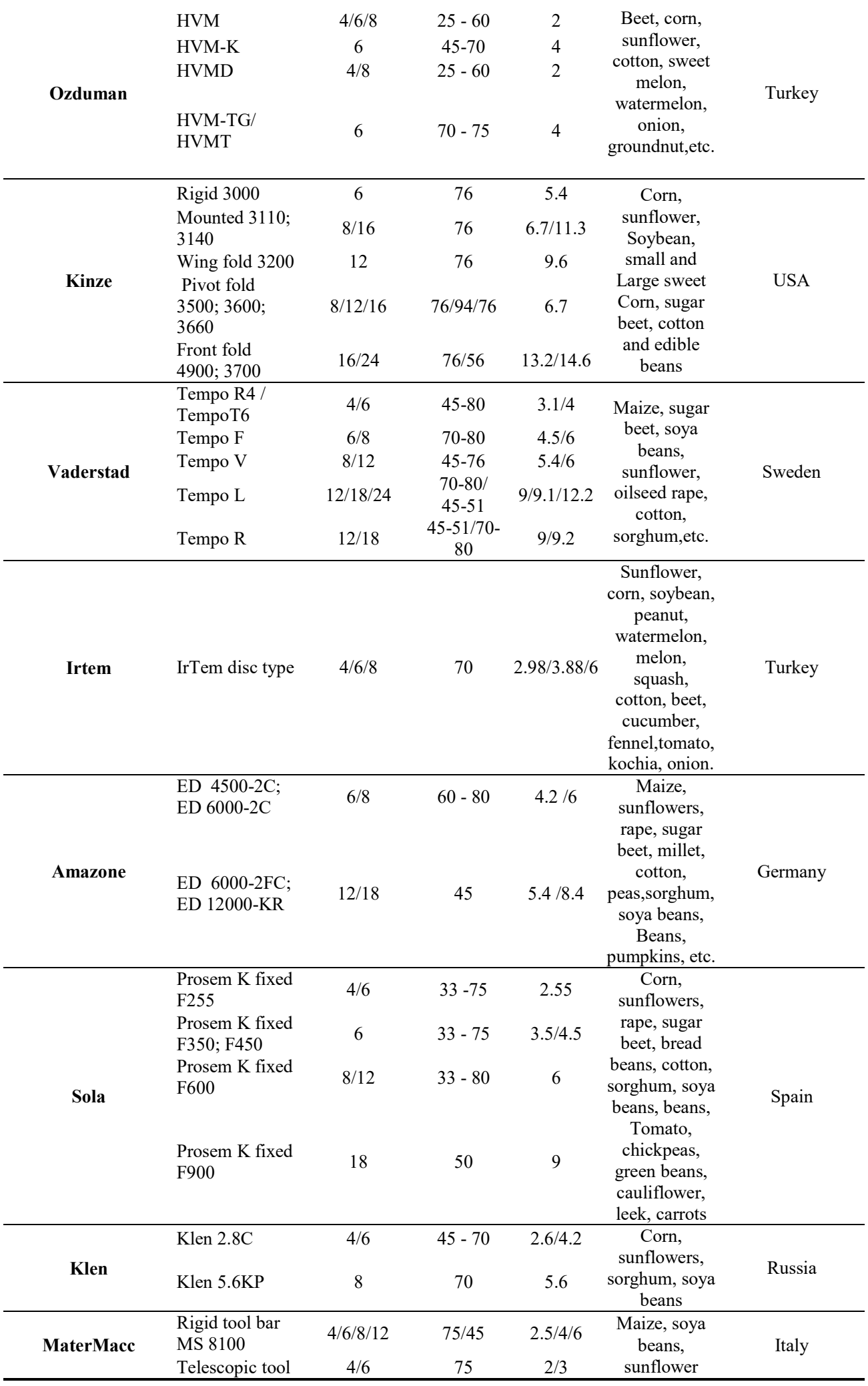




\section{Precision seed planters for tilled and non-tilled land}

Precision planters can be used for tilled and non-tilled land by mounted the soil and residue cutting device on planters. Tillage is used to prepare the soil before sowing many of crops and tillage methods differ from one country to another [3]. Despite, the primary objective of tillage is to destroy weeds and pests but is also important for improving the soil texture for high quality planting seeds, seed germination and for easy growing of seedling roots. Therefore, precision seed planters can be used with high accuracy, speed and efficiency. To achieve these requirements, development on seed meter, seed meter drive, seed control system and intelligent monitoring are occurring in a large and continuous manner on precision seed planters.

\subsection{Precision seed metering devices}

Seed metering device is used for transfer seeds from the seed box and deposit it into the delivery system that conveys the seeds into the seedbed. The aim of seed planting using precision planter is to achieve precise seed distribution within the row. The achievement of the set seed spacing majorly depends on the machine technical variables such as the type of seed meters, the planter forward speed, overall gear ratio between drive wheel and seed rotor, seed meter drive and to some extent on seed quality [4]. The good design of a seed metering unit is necessary for satisfactory performance of any precision planter. The assessment of distance between plants and seed rate as provided by the planters is also important in analyzing its performance. Therefore, seed meter is the most important part on planter and its performance affects the uniformity of seed distribution directly [5]. There are two kind of seed metering technology: pneumatic metering technology (i.e. vacuum seed meter, air pressure seed meter, finger pick-up seed meter and centralized pneumatic seed meter) and mechanical metering technology (i.e. plate seed meter, brush seed meter).For some type of seeds are light weight, low shear strength, good spherical shape, smooth skin and high oil content [6]. All these properties stand in the way of using mechanical precision seed metering. while it is difficult to control the seeding rate with more precisely, and the seed is tending to damage and Assembled into cell or jam socket of the device [7]. In fact, prefer to use pneumatic seed metering technology for precision seeding because the airflow reduces seed damage and there is no requirement to seeds grading due to its flexible characteristics, which has been widely used in precision seeding [8-10]. There is a large range of precision seed metering devices were innovated and developed to fit for precisionplanting under high working speed for different models (Table 2).

Table 2.Comparison of different type of seed meter for different types of precision seed planters.

\begin{tabular}{|c|c|c|c|c|}
\hline $\begin{array}{c}\text { Seed meter } \\
\text { type }\end{array}$ & Picture & Working rule & Features & $\begin{array}{c}\text { Planter } \\
\text { type }\end{array}$ \\
\hline $\begin{array}{c}\text { Plate } \\
\text { seed meter }\end{array}$ & & $\begin{array}{l}\text { The plate has several holes or cells. seed } \\
\text { cells around the seed disc periphery pick } \\
\text { up individual seed from the seed chamber. } \\
\text { With the rotation of the seed disc, the } \\
\text { seeds are transported downwards to } \\
\text { the seed delivery tube because of gravity. }\end{array}$ & $\begin{array}{l}\text { Need for seeds grading } \\
\text { and matched cells. } \\
\text { Require a longer } \\
\text { delivery tube. }\end{array}$ & $\begin{array}{l}\text { Kverneland } \\
\text { Monopill } \\
\text { models, } \\
\text { Kinze } \\
\text { Precision } \\
\text { models. }\end{array}$ \\
\hline
\end{tabular}




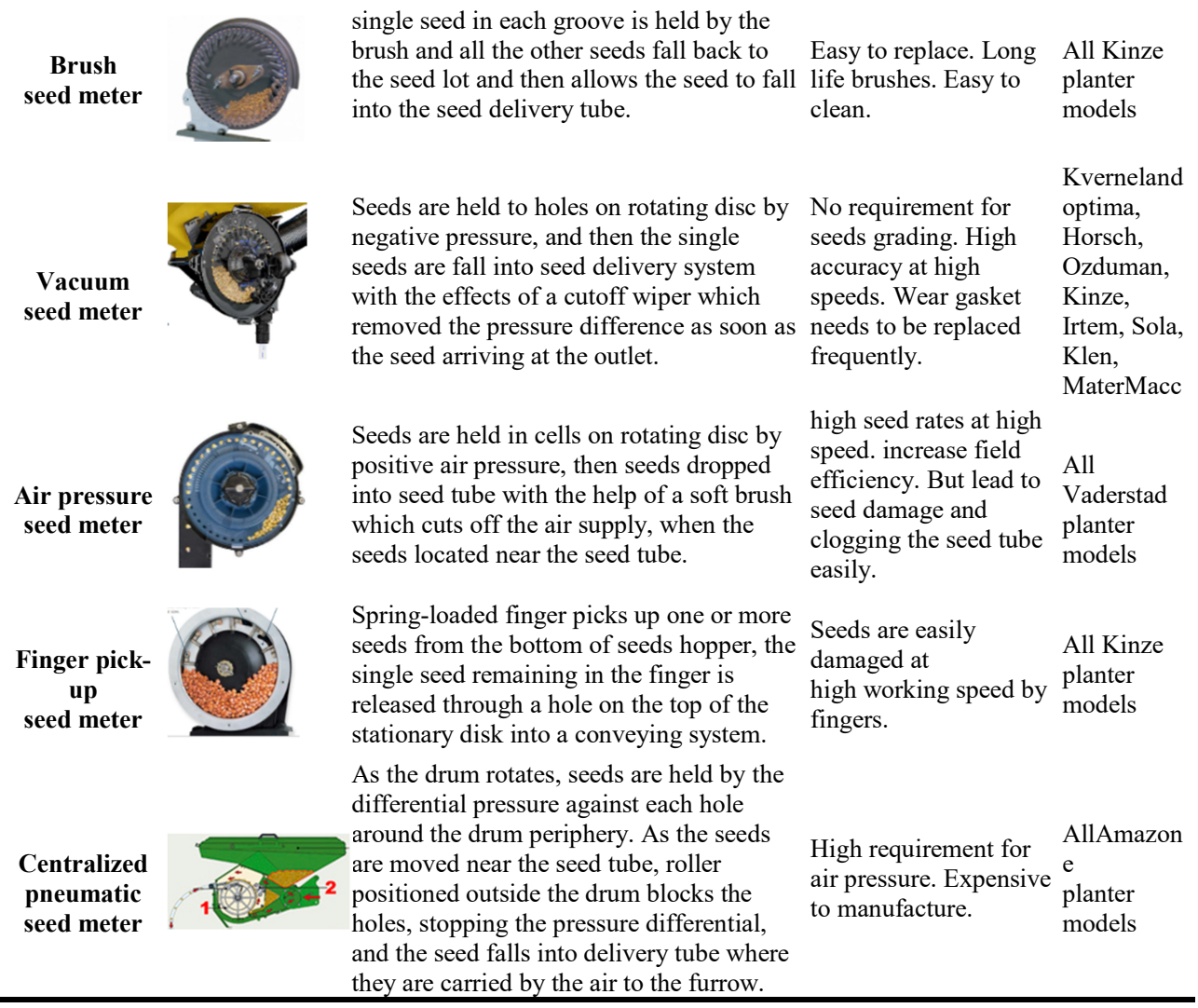

\subsection{Seed metering drive system}

Most seed metering driving systems for precision seed planter can be broadly classified as: mechanical, electrical, and hydraulically driving systems.

\subsubsection{Mechanical seed metering drive}

Mechanical seed metering drive unit currently perform their function effectively and it is a suitable solution to overcome the problem of seeds rate during precision planting,but there are many shortcomings of this method and can be avoided using an electrically or hydraulically driving systems and controlled seed meter unit. Mechanical driving system is easy to operate, smooth and reliable. A ground wheel speed or hydraulic motors are typically driven the mechanically seed meter driven devices, so these methods are a cost effective and effective solution. Modern ground contact drive systems are available for all kinze planter models except the 3660 , it is accurate, dependable, and easily adjustable for different seed rate, as well as there are no clutches and no chains to remove for transport, and they use spring-loaded tires to provide slip-free drive during operation [11] (Figure 1a). For all Monopill and Optima planter models, the mechanically driven seed meter device is used as standard, except the models; Monopill rigid frame 24 rows, Monopill parallel hydraulic folding 18 rows and Optima TF, while they only utilize electric drive. Amazone, MaterMacc, Sola, Ozduman and Irtem, companies of Germany, Italy, Spain and Turkey respectively, have developed the mechanical seed metering drive with automatic 
gearbox and use it as standard on all their precision seed planter models [12-17] (Fig. 1b 1e).

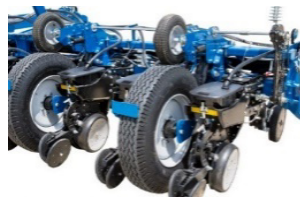

a. Kinze

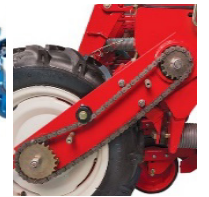

b. Ozduman

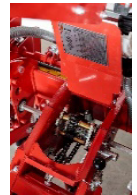

c. Irtem

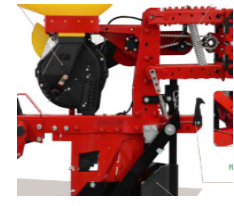

d. MaterMacc

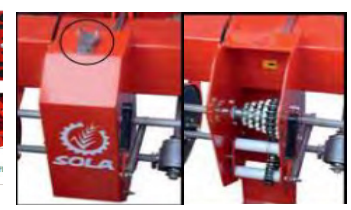

e. SOLA

Fig. 1.Driving seed meters using mechanical driving system for different types of precision seed planters.

\subsubsection{Electric seed metering drive}

Electric motor driven seed meters have numerous benefits and far ranging compared to conventional drive systems, and as a result, electric drives simplify maintenance as there are no longer drive chains, no driven by ground wheel, no drive shafts, no clutches and sprockets system. In addition, high accuracy planting cannot be occurred for traditional seed metering precision planters due to the sliding of ground wheel and chain vibration, especially at high forward speeds. To avoid these problems, the electrical motor was developed to be used as an alternative to the mechanical driving system to drive seed meters [17]. All precision seed planters' brands work from the same premise. Each sowing unit of the planter is driven individually via a small electric motor. The precision metering makes it possible to control the seeding rates of each rows and stop seeding, where there is no need for planting as well as on the move. For all Monopill and Optima planter models, the electric drive is used as standard, the electric motor is connected directly to the seed metering via a toothed belt in an encapsulated dust proof housing. This leads to an extremely compact design, low maintenance drive and smooth drive characteristics with reduce current consumption [18-19] (Figure 2a), except the Optima rigid and Optima hydraulic folding, which have the electric drive as optional not standard.Horsch and Vaderstad have made the electric seed metering drive technology standard on all their precision seed planter models. They developed a direct-driving method using a motor with gear reducer directly on the shaft of seed metering unit, consequently, the lateral size of the seed meters become larger [20,21] (Figures 2b and 2c). While Kinze is adding this technology only to the latest upgrades on its 4900 series planters (Figure 2d). Using electric seed meter drive given ability to handle any seed size or shape or even speed, and the plant spacing, as a result, it is used for all Klen precision seed planters' models [22] (Figure 2e).

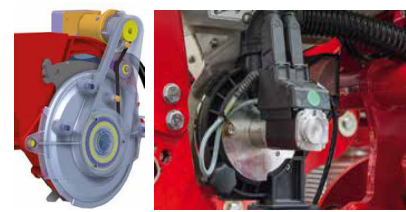

a. Kverneland

h. Horsch

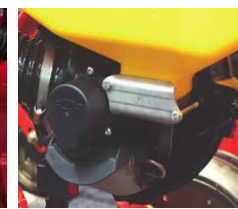

c. Vaderstad

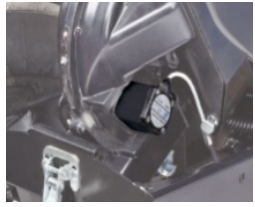

d. Kinze

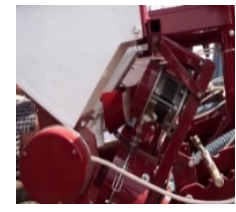

e. Klen

Fig. 2.Seed meter drive by DC motor for different types of precision seed planters.

\subsubsection{Hydraulic seed metering drive}


Precision planters lost their high performance and planting accuracy especially in the rough fields, where difficult interaction between the soil and the ground wheel of planter, which results in non-uniform seed planting. The non-precise seed distribution within the row would reduction the final crop yield production. Therefore to solve these problems, a mechanical driving system is replaced with electrical or hydraulic motors to drive seed meters, consequently, high seed rates can be metered without lowering the driving speed, and without changed any parts. This hydraulic drive system is suitable for variable seed rate and allow farmers to change seed rate from the seat of their tractor. Kinze has the hydraulic meter drive for many years, and it is currently available in the 3600, 3660, 3700 and 4900 models (Figure 3).Horsch and Amazone, a famous Germany planter companies, utilize currently hydraulic motor for driving seed meters on all their precision seed planter models, except theAmazone ED 12000-KR model, where it has only the mechanical drive system.

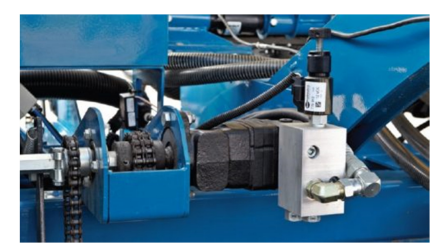

Fig. 3.Hydraulic seed metering drive for some models of Kinze precision seed planters.

\subsection{Seed delivery mechanism}

Precision sowing performance is mainly affected by the performance of seed metering device and the design structure of seed delivery. Seed delivery mechanism is mounted at the outlet of seed meter. It has a great importance in precision planter, as its main function is to convey the seeds from the seed meter on the soil surface or in the furrow smoothly and accuracy to maintain an equal spacing between the seeds along the furrow, thus the seed tube can improve the seeding quality. Seed delivery mechanisms in the study planters are divided into two main types: square seed tube and round seed tube delivery system.

\subsubsection{Square seed tube}

The square tube (Figure $4 \mathrm{a}$ ) is the most common seed delivery mechanism and widely used in the precision seed planter models (kinze, Horsch, Amazone, MaterMacc, etc.) compared to round seed tube. The main function of the square seed tube is to preserve the seeds that are drop out of the seed metering unit to the soil along its wall to keep the uniformity of seed distribution along the furrow. The shape of square seed tube is designed based totally at the trajectory of seed rate.

\subsubsection{Round seed tube}

Round seed tube is flexible hose, which is mainly used in air pressure seed meter. Vaderstad, a famous Germany planter company, was developed round seed tube (Figure $4 \mathrm{~b}$ ), which was mounted at the outlet of air pressure seed meter. When the seed reaches the seed tube, the air pressure is cut off and its effect is removed to accurately put the seed into the seed tube. During working, all seeds are granted the same transfer time from the seed meter down to the seed furrow, and it is not influenced by both slopes and vibration, therefore it allows planting with high seed rates and high seed spacing uniformity [23]. 


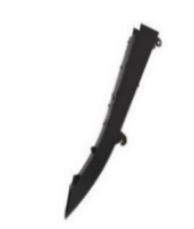

a. Square seed tube (Kinze)

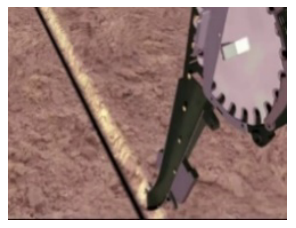

a. Square seed tube (Horsch)

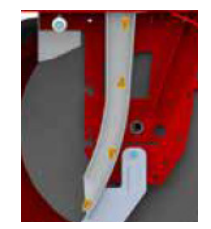

a. Square seed tube (MaterMacc)

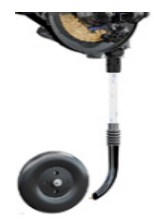

b. Round seed tube (Vaderstad)

Fig. 4.Different kinds of seed delivery mechanism for different types of precision seed planters.

\subsection{Planter monitoring sensor and seed control system}

The main goal of seed monitoring system is to observe seeds rate by each seed metering unit, as well as by the precision seed planter as whole. Seed sensor is the basis for measuring seed spacing uniformity with different types of seeds in the real-time, thus it is the most important part of the intelligent monitoring and control system. Optoelectronic sensors are widely used because of their low cost and high accuracy. The optical sensor is characterized by quite accuracy and produced in various forms depending on the working conditions, thus giving it extremely flexibility when mounted in the seed delivery mechanism. The sensor can be installed in different positions along the seed tube; input, middle or output of the seed tube. Horsch currently uses the optical sensor and fastened at the middle of square seed tube for monitoring the drilling accuracy process; measuring population, seed spacing, skips and doubles for all Horsch precision seed planter models (Figure 5a). The sensor detects each grain and sends it to the seed controller display. These evaluate the data and times between grain signals and use this information to calculate the variation coefficient, faults and double seeds. However, dust deposits in field adversely can be affected the sensor signals, and this can be the reason for incorrect data in the computer [24]. Because optical sensors utilize light beams, therefore that beam are susceptible falsely break from all things that can affect about that beam like interference from dust in field during planting. Optical sensors have some big problems as; count seeds and dust because they can't tell the difference between dust and seed, doubles look like singles, the problem of dust coating the sensor eyes and failing all together. To solve these problems, Kinze uses high-frequency radio waves sensor (Figure 5b) which developed by Precision Planting Inc. [25] to monitor seed mass instead of seed shape to avoid the influence and interference of dust during planting process. Radio wave sensor uses highfrequency waves to look at dropping seeds from different angle. This gives the sensor to distinguish a single seed from a double, dust or from any other material because they all register a different mass. It counts every seed and not dust, even at higher population rates and monitors multiples, skips and spacing between seeds. The radio waves also see through dust and that means the seed sensor is mounted at the bottom of the seed tube where it's the most accurate and automatically self-calibrates for dust [26]. Vaderstad has announced a new unique technology called Seed Eye for measuring seed spacing uniformity, as it currently utilizes an optical sensor illuminated by infrared light is placed in the seed tube (Figure 5c). The sensor constantly keep track of all the seeds that are being drilled as well as counting seeds based on seed weight. it detects if a seed tube has become blocked for any reason and gives an immediate warning to control system [27].

The monitor controller can easily set the population per hectare for different types of seeds according to signals received from seed sensor and it also displays all the parameters related to precision seeds planting on the screen. Kverneland company uses e-drive II in Monopill and Optima planter models for complete electronic monitoring of all precision 
planter functions from the tractor cab. This includes the seed monitoring by optoelectronic sensors. With e-drive II each sowing unit is driven individually via an electric motor. All the data is entered and read by an ISOBUS conform terminal like IsoMatchTellus Pro/GO that developed by kverneland for effective and easy operation for machines to reach the best performance and the highest productivity, as well as cost savings in fertilizer, chemicals and seeds. The sowing distances are infinitely adjustable on the move. All the sowing units can be switched off individually (Figure 6a) [28]. Every Horsch seed planter models are always equipped with the ISOBUS section control which allows for switching on and off individual sections automatically like fertilizer and seed at the right time via GPS. All Horsch seed drill has ISOBUS terminal, section control, variable rate and task controller to make precision planting with work even more efficiently and help farmers to save both money and increase confidence (Figure 6b) [29]. Kinze company utilize KPM III electronic seed monitor which is easy to use, economical, give results by monitors up to 36 rows in the same time, skips, multiples, planting rate, ground speed, row spacing, seed population of rows, average seed population and distance between seed along the furrow for its all row crop planter models except model 3660 . Kinze also use ISOBUS-compatibility task controller-equipped display for its row crop planters in models; 3200, 3600, 3660, 3700 and 4900. With ISO compatibility, split screen view so both tractor and planter are controlled through one monitor, determining seed rates and advanced planter control (Figure 6c) [30]. Vaderstad uses a modern E-control system wirelessly connects to the planter enabling full access to its functions and data. Vaderstad E-control is a fully portable monitoring and control system able to adjust the working depth, change the planting rate and monitor planting precision via portable iPad. Vaderstad also uses ISOBUS terminal which able to take control over tasks such as planter control and troubleshooting. ISOBUS terminal and Vaderstad E-control can be used simultaneously. They used for monitoring and control planting process at real time (Figure 6d) [31]. Irtem company use seed control system for its all planter models which can be monitored the sowing area skips and seed population. Additionally, all the sowing units can be stopped individually (Figure 6e) [32]. Amazone company uses from simple electronic up to ISOBUS technology for its all planter models. Where the mechanical drive can be controlled via the simple electronic equipment with AMASCAN+ monitor. During planting, the accurately sown number of grains per ha is displayed on the monitor and every sowing unit can be switched off individually via AMASCAN+ monitor, which is joined with opto-sensors. ISOBUS terminals like AMATRON 3, CCI 100 or AMAPAD terminal are available for its all precision air seeder models. The ISOBUS terminal allows overall monitoring of the planter and quick adjustment possibility. In addition to checking of the opto- sensors (Figure 6f) [33]. Sola company utilizes electronic monitor for controlling all functions of the planter, as optional, including centralized seed system, etc. [34]. klen planter is equipped with electronic remote-control system for monitoring the sowing process using remote control. It provides high precision planting, equal distance between plants, setting speed and no mechanical damage to seeds(Figure 6h) [35]. Models of studied precision planters associated with the technologies mentioned above are as follows (Table 3).

Table3.Comparison of some monitoring and control technology for precision sowing using different types of precision planters.

\begin{tabular}{lccccc}
\hline Machine name & $\begin{array}{c}\text { Row } \\
\text { number }\end{array}$ & $\begin{array}{c}\text { Type of seed } \\
\text { meter }\end{array}$ & $\begin{array}{c}\text { Seed } \\
\text { metering } \\
\text { drive }\end{array}$ & $\begin{array}{c}\text { Seed } \\
\text { monitoring } \\
\text { sensor }\end{array}$ & $\begin{array}{c}\text { monitor } \\
\text { controller }\end{array}$ \\
KvernelandMonopill & $6-24$ & $\begin{array}{c}\text { Plate seed } \\
\text { meter }\end{array}$ & $\begin{array}{c}\text { Mechanical, } \\
\text { Electric }\end{array}$ & $\begin{array}{c}\text { Opto- } \\
\text { electronic } \\
\text { sensor }\end{array}$ & $\begin{array}{c}\text { IsoMatchTellus } \\
\text { Pro/GO }\end{array}$ \\
\hline
\end{tabular}




\begin{tabular}{|c|c|c|c|c|c|}
\hline Kverneland Optima & $6-18$ & $\begin{array}{c}\text { Vacuum seed } \\
\text { meter }\end{array}$ & $\begin{array}{c}\text { Mechanical, } \\
\text { Electric }\end{array}$ & $\begin{array}{c}\text { Opto- } \\
\text { electronic } \\
\text { sensor } \\
\end{array}$ & $\begin{array}{c}\text { IsoMatchTellus } \\
\text { Pro/GO }\end{array}$ \\
\hline HORSCH & $6-24$ & $\begin{array}{c}\text { Vacuum seed } \\
\text { meter }\end{array}$ & $\begin{array}{l}\text { Electric, } \\
\text { Hydraulic }\end{array}$ & $\begin{array}{c}\text { Opto- } \\
\text { electronic } \\
\text { sensor }\end{array}$ & $\begin{array}{c}\text { ISOBUS } \\
\text { Technology }\end{array}$ \\
\hline Ozduman & $4 / 6 / 8$ & $\begin{array}{c}\text { Vacuum seed } \\
\text { meter }\end{array}$ & Mechanical & - & - \\
\hline Kinze & $6-24$ & $\begin{array}{l}\text { Finger pick- } \\
\text { up, vacuum } \\
\text { and Brush } \\
\text { seed meter }\end{array}$ & $\begin{array}{c}\text { Mechanical, } \\
\text { Electric and } \\
\text { hydraulic }\end{array}$ & $\begin{array}{c}\text { Radio wave } \\
\text { sensor }\end{array}$ & $\begin{array}{c}\text { KPM III } \\
\text { electronic seed } \\
\text { monitor } \\
\text { ISOBUS- } \\
\text { compatibility }\end{array}$ \\
\hline Vaderstad & $4-24$ & $\begin{array}{l}\text { Air pressure } \\
\text { seed meter }\end{array}$ & Electrical & $\begin{array}{c}\text { Opto- } \\
\text { electronic } \\
\text { sensor } \\
\end{array}$ & $\begin{array}{c}\text { E-control and } \\
\text { ISOBUS } \\
\text { terminal }\end{array}$ \\
\hline Irtem & $4 / 6 / 8$ & $\begin{array}{c}\text { Vacuum seed } \\
\text { meter }\end{array}$ & Mechanical & - & $\begin{array}{c}\text { Electronic seed } \\
\text { monitor }\end{array}$ \\
\hline Amazone & $6-18$ & $\begin{array}{c}\text { Centralized } \\
\text { drum seed } \\
\text { meter }\end{array}$ & $\begin{array}{c}\text { Mechanical, } \\
\text { hydraulic }\end{array}$ & $\begin{array}{l}\text { Opto- } \\
\text { electronic } \\
\text { sensor }\end{array}$ & $\begin{array}{c}\text { AMASCAN+ } \\
\text { monitor, } \\
\text { ISOBUS } \\
\text { terminals } \\
\text { (AMATRON 3/ } \\
\text { CCI 100/ } \\
\text { AMAPAD) }\end{array}$ \\
\hline Sola & $4-18$ & $\begin{array}{c}\text { Vacuum seed } \\
\text { meter }\end{array}$ & Mechanical & - & $\begin{array}{c}\text { Electronic seed } \\
\text { monitor }\end{array}$ \\
\hline Klen & $4 / 6 / 8$ & $\begin{array}{c}\text { Vacuum seed } \\
\text { meter }\end{array}$ & Electric & - & $\begin{array}{c}\text { Electronic } \\
\text { remote-control } \\
\text { monitor }\end{array}$ \\
\hline MaterMacc & $4-12$ & $\begin{array}{c}\text { Vacuum seed } \\
\text { meter }\end{array}$ & Mechanical & - & - \\
\hline
\end{tabular}

- Not available

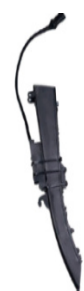

a. Opto-electronic sensor installed in the middle of square seed tube (Horsch)

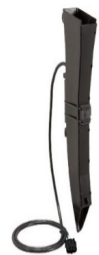

b. Radio wave sensor installed at the outlet of seed tube (Kinze)

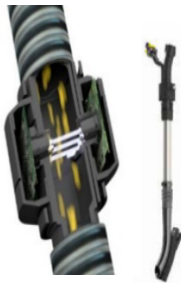

c. Opto-electronic sensorinstalled in the middle of round tube (Vaderstad)

Fig.5.Different kinds of planter monitoring sensor for precision planting. 


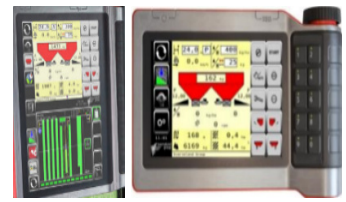

a. IsoMatchTellus Pro/GO (Kverneland)

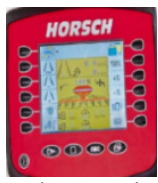

b. Horsch terminal

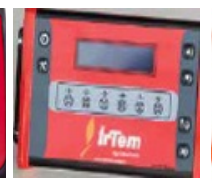

e.

Irtemscre

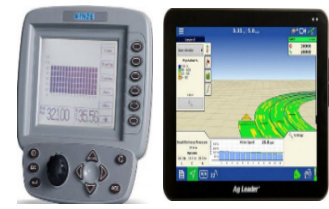

c. KinzeKPM III and ISOBUS display
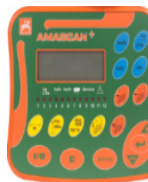

f. AMASCAN+ and Amazone ISOBUS terminals (AMATRON 3, CCI 100 and AMAPAD)

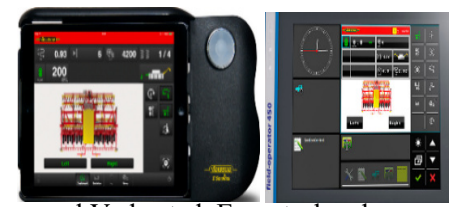

d.Vaderstad E-control and ISOBUS terminal

Fig.6.Different types of planter monitor controller for precision planting

\subsection{Precision planter soil-engaging components}

The functions performed by the soil-engaging components include penetrate the soil during the seeding operation which enable placing the seed, pesticides and fertilizers at the desired depth, covering and pressure the seed furrow. It clearly differs from one planter type to another and from model to another inside the same type, where the possibility of adding or removing some parts depending on the purpose of the planter for precision planting (Table 4).

KvernelandMonopill series planter is a mechanical precision seed planter with varies working width which designed for professional precision drilling of beet, rape and chicory, with double disc for fertilizer, runner coulter for furrow opening, covering press rubber wheel (zero pressure press rubber wheel) with self-cleaning rubber ring and as option it can be replaced with V- finger rubber wheel for covering seeds as well as mini seed hopper, microgranular applications and fertilizer hoppers. The opto-electronic sensor monitors and controls the correct position of seeds on the disc. Peripheral speed of the plate seed meter matches exactly the forward speed of the planter; therefore, the seed has "zero speed effect" which eliminates seed bounce. However, the working speed should not increase than 8 $\mathrm{km} / \mathrm{h}$, because that will lead to a significant decrease of planting quality [36].

Kverneland Optima series planter is the universal pneumatic precision seed planters which are equipped with an improved vacuum seed meter, which makes it more suitable for a wide variety of seed types. Kverneland invented seeding heart for all optima series which is characterized by less friction, no wear, minimum maintenance and low torque. Easy exchange of various coulters and press wheels depending on seed type and soil conditions. Where double disc opener for hydraulic folding and TFprof and TFmaxi models while runner coulter is used for furrow opening in rigid models, seed covering rubber press wheel and double disc for fertilization purposes. Optima series distinguish by big seed hopper with a capacity of 50 liters and high working speed compared with Monopill series of 9 liters, whilst exact seed precision placement at speed up to $12 \mathrm{~km} / \mathrm{h}$ [37].

HORSCH Maestro series is designed with advanced vacuum seed meter which makes it more suitable for all types of single grain sowing with efficient and flexible. The distinguishing feature of Maestro precision planters is the hydraulic control system for all functions, which has a high coulter pressure up to $300 \mathrm{~kg}$ that can be adjusted centrally via a hydraulic drive which helps to put seeds on the required depth as well as precise seed placement at high sowing speed up to $12 \mathrm{~km} / \mathrm{h}$. It supplied with double disc for fertilizer, double disc coulter for furrow opening, double finger wheel for row preparation and 
covering V- press rubber wheel which it can be replaced with finger wheel and inclined press rubber wheel combination for closing the seed channel and press the soil against the seed. Each row units have large seed hoppers with a capacity of 70 liters for Maestro CC and RC, while seed hopper capacity is 2,000 liters for Maestro SW as a central hopper. The electronic control system monitors the seeds accurately during the process of precision planting [38].

Ozduman precision series planter was developed with different models to maintain uniform seed distribution along the row for a wide variety of seed shapes and sizes on all kinds of soil conditions and dropping fertilizer and seed into the equal depth. Tine, blade, runner types and covering rubber press wheel were used for fertilizer, row preparation, furrow opening and covering seeds respectively for both HVM and HVM-K models. But for all other Ozduman precision planters, are used double disc for fertilizer, double finger wheel for row preparation, double disc coulter for furrow opening and V-press rubber wheel for closing the seed channel and press the soil [39].

Kinze precision series planter is equipped with high precision seed metering units like finger pickup, brush or vacuum to maintain uniform seed distribution under all soil conditions. Every precision planter model is characterized by the possibility of adding fertilizers, whether liquid or solid, during the cultivation process except for planters 3100 and 3140. Either a single fluted disc or single notched disc are used for soil and residue cutting and adding liquid fertilizer, single finger wheel is used only for row preparation in models 3100, 3200, 3700 and 4900. while double disc coulter and V-press rubber wheel are used for furrow opening and covering seeds for all Kinze models. The distinguishing feature of some Kinze planter models is the split rows which enables the sowing of two different types of seeds at the same time or cultivate one seed but a narrow distance between the rows [40].

Vaderstad Tempo series planter is developed to delivering an unmatched precision at very high speed of 10 to $17 \mathrm{~km} / \mathrm{h}$, as well as full control of seed delivery, from the seed meter to the seed tube until reaching the soil. It is designed not to be affected by vibrations or slopes on the precision of the seed metering, so it puts seeds into the equal depth along the furrow in uneven field conditions. It supplied with single notched disc for soil and residue cutting, double finger wheel for row preparation, double disc coulter for furrow opening, and V-press rubber wheel for covering seeds [41].

Irtem disc series planter is designed to make sowing seeds with high depth precision, without any effect from straw waste on the field under any kind of soil and climate conditions. It used a single disc for adding fertilizer, blade type for row preparation, double disc for furrow opening and dropping seeds in the suitable depth and V-press rubber wheel for covering seeds [42].

Amazone ED precision series planter is equipped with a suitable singling disc which can be matched to almost any seed type, therefore it gives a precise seed placement and very accurate singling system under high planting speed up to $15 \mathrm{~km} / \mathrm{h}$. It also equipped with a single-disc fertilizer opener, a double-disc coulter for furrow opening, an electric drive for the fertilizer metering as well as hydraulic singling drive. After dropping, V- press wheel is used for placing and firming seeds to improve the planting precision [43].

Sola Prosem K fixed series planter isconsisting of a single disc for adding fertilizer, blade type for row preparation, double disc for furrow opening and V-press rubber wheel for covering seeds to maintain uniform seed distribution. The planter is suitable for precision planting under the working speed of 5 to $10 \mathrm{~km} / \mathrm{h} \mathrm{[44].}$

Klen precision series planter is equipped with high vacuum seed metering to keep uniform seed distribution under working conditions which is suitable for precision planting under the working speed of 1 to $7 \mathrm{~km} / \mathrm{h}$. Double disc coulter and press rubber wheel are used for furrow opening and covering seeds for klen models $2.8 \mathrm{C}$, while for klen planter 
5.6C is used a double disc for adding fertilizer, double disc for opening and adding seeds in furrow as well as press wheel for covering seeds and press the soil [45].

MaterMacc MS 8100 and MS 8130 series planter was developed with different models which characterized for its simple structure and have a low overhanging weight. For MS 8100 models are used tine type, double disc and covering rubber press wheel for fertilizer, furrow opening and covering seeds respectively, while for MS 8130 models are used a double disc for both adding fertilizer and furrow opening, in addition to V-press rubber wheel for covering the seeds. The planters are suitable for precision planting under the working speed of $6.9 \mathrm{~km} / \mathrm{h}$ [46].

Table 4.Comparison of planter soil-engaging components and working speed for different types of precision planters.

\begin{tabular}{|c|c|c|c|c|c|}
\hline Machine name & $\begin{array}{l}\text { soil and residue } \\
\text { cutting type }\end{array}$ & $\begin{array}{l}\text { Row preparation } \\
\text { device type }\end{array}$ & $\begin{array}{c}\text { Furrow opening } \\
\text { device type }\end{array}$ & $\begin{array}{l}\text { Minimum } \\
\text { power /hp }\end{array}$ & $\begin{array}{c}\text { Working } \\
\text { speed } \\
/ \mathrm{km} \cdot \mathrm{h}-{ }^{1}\end{array}$ \\
\hline $\begin{array}{l}\text { KvernelandMonopill } \\
\text { series }\end{array}$ & Double plain disc & Roller type & Runner coulter & $>50$ & 7.5 \\
\hline $\begin{array}{l}\text { Kverneland Optima } \\
\text { series }\end{array}$ & Double notched disc & $\begin{array}{c}\text { Rollertype/ } \\
\text { Double finger } \\
\text { wheel } \\
\end{array}$ & $\begin{array}{l}\text { Runner coulter/ } \\
\text { Double disc coulter }\end{array}$ & $>50$ & 12 \\
\hline $\begin{array}{l}\text { HORSCH Maestro } \\
\text { series }\end{array}$ & Double plain disc & $\begin{array}{c}\text { double finger } \\
\text { wheel }\end{array}$ & Double disc coulter & $>100$ & 12 \\
\hline $\begin{array}{l}\text { Ozduman precision } \\
\text { planters }\end{array}$ & Double Plain disc & $\begin{array}{c}\text { Blade type/ } \\
\text { Double finger } \\
\text { wheel } \\
\end{array}$ & $\begin{array}{c}\text { Runner type/ } \\
\text { Double disc coulter }\end{array}$ & $>60$ & $6-8$ \\
\hline $\begin{array}{l}\begin{array}{l}\text { Kinze precision } \\
\text { planters }\end{array} \\
\end{array}$ & $\begin{array}{l}\text { Single fluted disc / } \\
\text { Double plain disc }\end{array}$ & $\begin{array}{c}\text { Single finger } \\
\text { wheel }\end{array}$ & Double disc coulter & $>100$ & $8-12$ \\
\hline $\begin{array}{l}\text { Vaderstad Tempo } \\
\text { series }\end{array}$ & Single notched disc & $\begin{array}{c}\text { Single finger } \\
\text { wheel }\end{array}$ & Double disc coulter & $>70$ & $10-17$ \\
\hline Irtem disc series & Single plain disc & Blade type & Double disc coulter & $>80$ & $5-7$ \\
\hline $\begin{array}{l}\text { Amazone ED } \\
\text { precision planters }\end{array}$ & Single plain disc & - & $\begin{array}{c}\text { Runner coulter/ } \\
\text { Double disc coulter }\end{array}$ & $>100$ & 15 \\
\hline $\begin{array}{l}\text { SolaProsem K fixed } \\
\text { series }\end{array}$ & Single turbo disc & Blade type & Double disc coulter & $>50$ & $5-10$ \\
\hline $\begin{array}{l}\text { Klen precision } \\
\text { planters }\end{array}$ & Double Plain disc & - & Double disc coulter & $>50$ & $1-7$ \\
\hline $\begin{array}{l}\text { MaterMaccMS } 8100 \\
\text { and MS } 8130 \text { series } \\
\text { planter }\end{array}$ & Double Plain disc & Blade type & Double disc coulter & $>50$ & 6.9 \\
\hline
\end{tabular}

\subsection{Fertilizer and seed hopper capacity}

The fertilizer hopper capacity whether; dry, liquid or micro fertilizer, is different from one precision seed planter to another. There is also a difference in the seed hopper capacity for both seed single hopper for each row or the central hopper of the whole planter (Table 5).

Table 5.Comparison of fertilizer and seed hopper capacity for different types of precision planters.

\begin{tabular}{|c|c|c|c|c|c|c|c|}
\hline \multirow{2}{*}{\multicolumn{2}{|c|}{ Machine name }} & \multirow{2}{*}{$\begin{array}{c}\text { fertilizer } \\
\text { opener type }\end{array}$} & \multicolumn{3}{|c|}{ Fertilizer hopper capacity (I) } & \multicolumn{2}{|c|}{ Seed hopper capacity (I) } \\
\hline & & & Dry & Liquid & $\begin{array}{l}\text { micro } \\
\text { fertilizer }\end{array}$ & $\begin{array}{l}\text { Single per } \\
\text { row }\end{array}$ & Central \\
\hline \multicolumn{2}{|c|}{ KvernelandMonopill series } & Double disc & 0 & - & 0 & 9 & - \\
\hline \multirow{2}{*}{$\begin{array}{c}\text { Kverneland } \\
\text { Optima }\end{array}$} & $\begin{array}{l}\text { Rigid, Hydraulic } \\
\text { fold }\end{array}$ & \multirow{2}{*}{ Double disc } & & - & 0 & 55 & - \\
\hline & Tfprofi, TF maxi & & O & - & - & 55 & - \\
\hline HORSCH & Maestro CC & Double disc & $\mathrm{O}$ & - & - & 70 & - \\
\hline
\end{tabular}




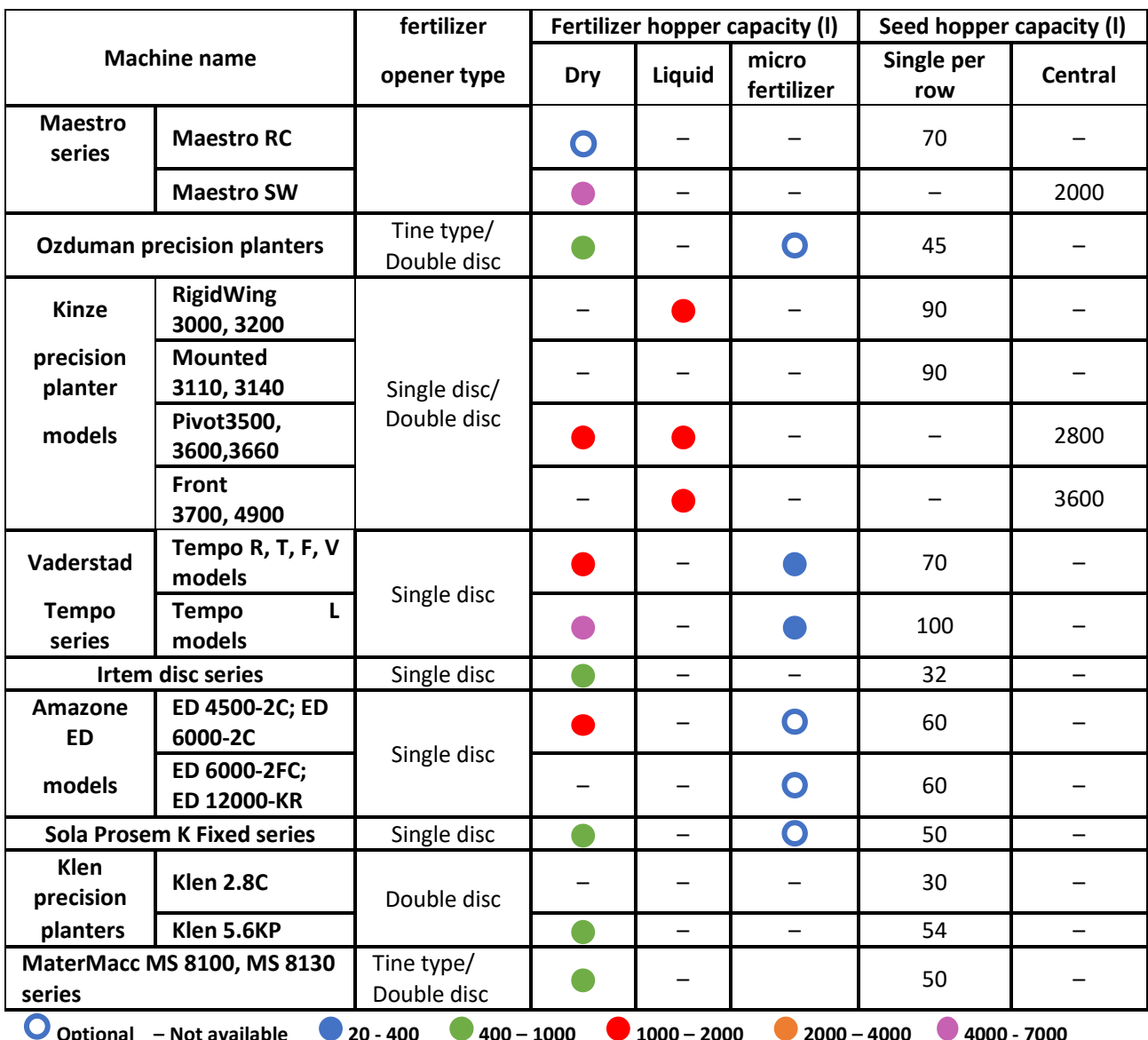

\subsection{Matched power}

Selecting of suitable size tractor for the precision seed planter is a very important factor, especially in economic terms. The select of the power requirement depends mainly on several factors; basic weight of version, working width, type of seed meter andits driven, type of fertilization unit and its operation method as well as planter soil-engaging components. The number of planting rows varies from one precision seed planter to another according to the working width per planter. The number of rows were classified to $4,6,8$, 12,18 and 24 rows and then the different types of weight basic planter were compared with the horsepower requirement per meter of the working width for different models (Fig7), where it allows to evaluate and choose the appropriate planter type in terms of the number of rows, working width and the power required for this planter. The obtained results for 4 rows showed that the lowest values for weight of basic version were 750 and $720 \mathrm{~kg}$ and minimum power requirement per each meter working width were 19.2 and $20 \mathrm{hp} / \mathrm{m}$ for the Klen 2.8C and MaterMacc MS 8100 planter models respectively. While for 6 rows, the lowest basic weights were 400,1000, 1170 and $1120 \mathrm{~kg}$ for KvernelandMonopill rigid, Ozduman HVM-T, MaterMacc MS 8130 and Klen 2.8C planters respectively, but the minimum power requirement per meter working width were $16.7,18,20 \mathrm{hp} / \mathrm{m}$ for Klen 2.8C, KvernelandMonopill rigid and Ozduman HVM-T planters respectively.For 8 rows the best values for both basic weight and minimum matched power are 1270, 1450, $1600 \mathrm{~kg}$, 15, 16.1, $16.7 \mathrm{hp} / \mathrm{m}$ for MaterMacc MS 8100,Klen 5.6KP and Sola Prosem F600/8 
precision planters respectively.For 12 rows, KvernelandMonopill has lower values for both basic weight and minimum power per meter working width, where the values were $910 \mathrm{~kg}$ and $15.7 \mathrm{hp} / \mathrm{m}$ and then minimum power is $16.7 \mathrm{hp} / \mathrm{m}$ for both of Monopill hydraulic, optima Hydraulic and MaterMacc MS 8100 models, but the weights were different as 1250 , 2600 and $1690 \mathrm{~kg}$ respectively.For the large number of rows, 18 rows, the minimum power required were 13.3, 15 and 17, $1 \mathrm{hp} / \mathrm{m}$ for Sola Prosem F900, Monopill rigid and Monopill hydraulic but with different weights were 2710,1750 and $2180 \mathrm{~kg}$ respectively. For the 24 rows, the Monopill rigid has a lower weight $(2800 \mathrm{~kg})$ and minimum power per meter width $(12.3 \mathrm{hp} / \mathrm{m})$ than other models. Values for weight of basic version and minimum power for both Kinze and Amazone precision seed planter are not available as well as the weights for Kverneland optima models. Finally, the minimum power requirement for the precision planter and its relation to the weight of version is one of the most important factors for selecting the precision seed planter, especially for small farm scale and rough surface hilly as well as economic terms.

\section{Conclusions and recommendations}

Currently, due to the importance of increasing crop production, the precision planters are developed continuously and significantly.Therefore, there are some factors that distinguish some types of plantercompared to others, and they are taken into consideration when choosing the appropriate precision seed planter type.

1. Farmers need to plant seeds in a short period with high working speed and high efficiency to preserve seed quality while saving time and costs. This is achieved by using high speed precision planters with big working width, and this is what is distinguishes the Vanderstad Tempo L and Amazone ED 6000-2FC planter with high working speeds of 15 $\mathrm{km} / \mathrm{h}$ or more and 12.2 and 8.4 working widthrespectively. As the working speed of both Kverneland OptimaTF maxi, Horsch Maestro SW and Kinze folding 4900 planters are 12 $\mathrm{km} / \mathrm{h}$ with different working width of $12,17.4$ and 14.6 respectively for planting 24 rows.

2. Using electrical or hydraulically motors for driving seed meter are the effective methods to maintain the uniformity of seed distribution and high accuracy planting compared with mechanical drive due to the sliding of ground wheel and chain vibration especially at high forward speeds. 

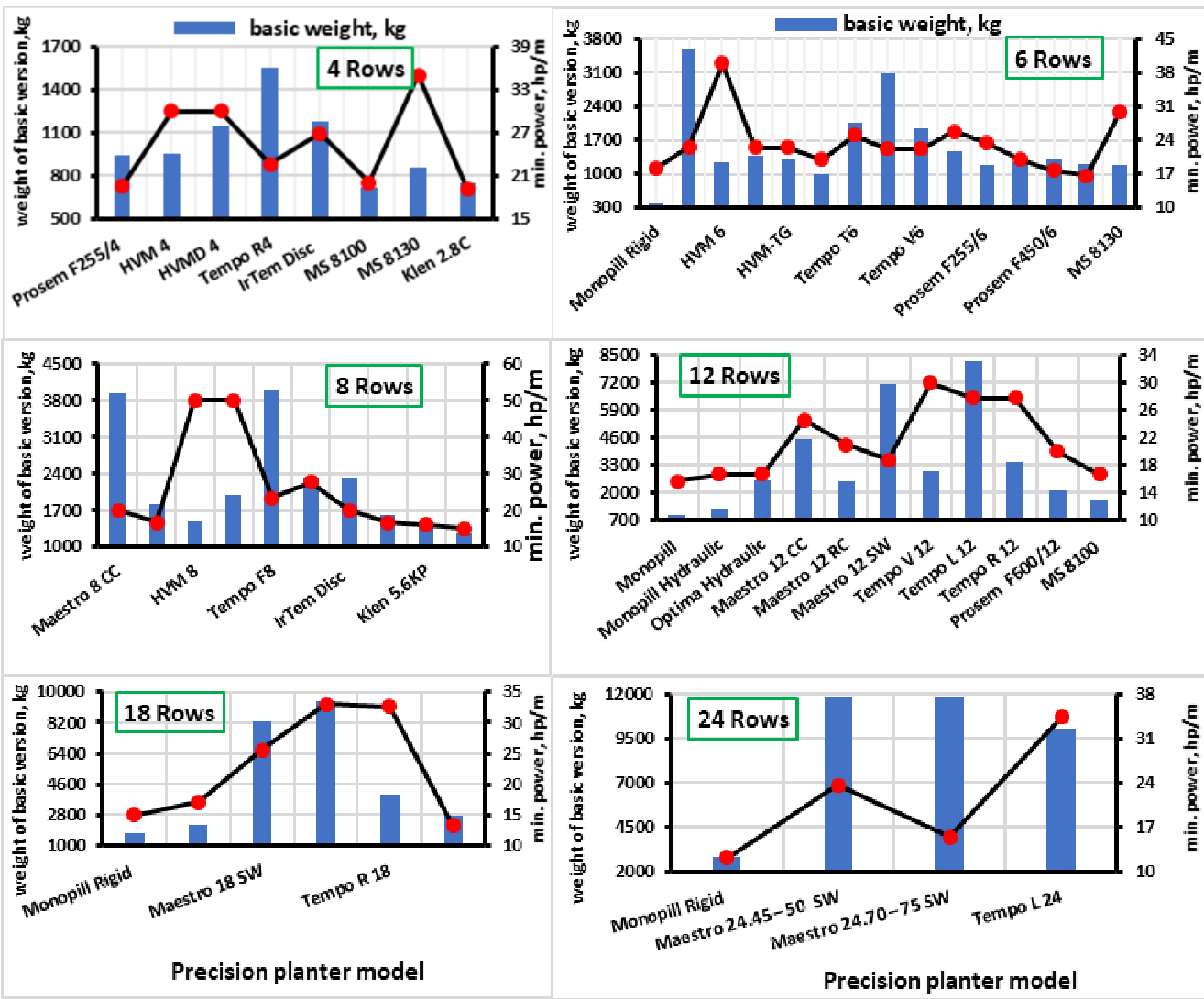

Fig. 7.Minimum power requirement per meter working width $(\mathrm{hp} / \mathrm{m})$ and weight of basic version $(\mathrm{kg})$ for different planters' models.

3. To ensure uniform seeding depth, different kinds of depth control units were developed to maintain optimal depth control. Therefor some precision planters are equipped with hydraulic driving depth control unit which is the most effective way to keeps the seed depth at all times and under differing field conditions. Vanderstad Tempo series planter can apply either positive or negative pressure by hydraulic weight transfer, while Horsch Maestro seriesplanter $\mathrm{c}$ has a high coulter pressure hydraulic up to $300 \mathrm{~kg}$ that can be adjusted centrally via a hydraulic drive which helps to put seeds on the required depth. Additionally, it can be easily controlled via the control system from the tractor cab.

4. For small farm size and rough surface hilly, seed planters need to be lightweighted, small sized and need to low horsepower requirements. This is a feature of some small size planters for some models of Klen, MaterMacc, Kverneland, Ozduman and Sola precision planters. for 4 rows, the values for basic weight were 750 and $720 \mathrm{~kg}$ and minimum power requirement per meter working width were 19.2 and $20 \mathrm{hp} / \mathrm{m}$ for the Klen 2.8C and MaterMacc MS 8100 precision planters respectively. While for 6 rows, values were 400, 1000, 1170 and $1120 \mathrm{~kg}$ for KvernelandMonopill rigid, Ozduman HVM-T, MaterMacc MS 8130 and Klen 2.8C planter models, but the minimum power requirement were 16.7, 18, $20 \mathrm{hp} / \mathrm{m}$ for Klen 2.8C, KvernelandMonopill rigid and Ozduman HVM-T planters respectively. For 8 rows the best values for both basic weight and minimum matched power are 1270, 1450, $1600 \mathrm{~kg}, 15,16.1,16.7 \mathrm{hp} / \mathrm{m}$ for MaterMacc MS 8100, Klen 5.6KP and Sola Prosem F600/8 precision seed planters respectively. 
5. The distinguishing feature of Kinze planter models; 3200, 3600, 3660, 3700 and 4900 is the split rows which enables the sowing of two different types of seeds at the same time or cultivate one seed but a narrow distance between the rows.

6. The medium size precision planters should be developed with a higher operating speed with higher planting precision to increase working efficiency, which is used in medium-sized lands.

7. Most of the precision planters are manufactured in developed countries and some types of these are exported to developing countries. However, their usage in these areas are limited due to differences of crop type, climate conditions, geography, farm scale and economic status, so it must be developed according to local condition in developing countries.

\section{References}

1. OECD/FAO, OECD Publishing, OECD-FAO Agricultural Outlook 2018-2027 (2018) https://doi.org/10.1787/agr_outlook-2019-en

2. S. Kambulov, MATEC, 224, 05022 (2018) doi: 10.1051/matecconf/201822405022

3. L. Yang, B. X.Yan, Y. M. Yu, X. T.He, Q. W.Liu, Z. J.Liang, et al.,Int J Agric\&Biol Eng.9(1), 9-26 (2016) https://doi.org/10.3965/j.ijabe.20160901.2285

4. B.S.Reddy, Satyanarayana, R.V. Adake,M. Anantachar, Indian J. Dryland Agric. Res. \& Dev.27(2), 36-42 (2012)

5.A. Yazgi, A. Degirmencioglu, Journal of the International Measurement Confederation? 56, 128-135 (2014) https://doi.org/10.1016/j.measurement.2014.06.026

6. X. Li, Q. X.Liao, J. J.Yu, C. X.Shu, Y. T.Liao, Journal of Food Agriculture \& Environment, 10(1), 450-454 (2012)

7. J. J. Yu, Y. T. Liao, J. L. Cong, S. Yang, Q. X. Liao, IntAgri\&Biol Eng, 7(3), 1-12 (2014) doi: 10.3965/j.ijabe.20140703.001

8. G. Z. Zhang, Y. Zang, X. W. Luo, Z. M. Wang, Q. Zhang, S. S. Zhang, IntAgri\&Biol Eng., 8(4), 10-18 (2015) doi:10.3965/j.ijabe.20150804.1626

9. L. J. Liu, H. Yang, S. C. Ma, IntAgri\&Biol Eng. 9(6), 84-90 (2016) doi: 10.3965/j.ijabe.20160906.2129

10. C. L. Searle, M. F. Kocher, J. A.Smith, E. E. Blankenship, Applied Engineering in Agriculture, 24(5), 581-586 (2008)

11. Kinze precision seeder. Available: https://www.kinze.com/planters/4900-planter . Accessed on [2019.09.15]

12. Ozduman pneumatic seeder. Available: http://ozduman.com/en-US/product/seedinggroup/1056.Accessed on [2019.09.15]

13. Irtem pneumatic planter. Available: http://www.irtem.com.tr/en/pneumatic-precisionplanter. Accessed on [2019.09.15]

14. MaterMacc vacuum precision planter. Available: http://www.matermacc.it/eng/seminatrici.html. Accessed on [2019.09.15]

15. Sola precision planter. Available: https://solagrupo.com/en/ct/precision-planters- 11 . Accessed on [2019.09.15]

16. Amazone precision air seeder. Available: http://www.amazone.net/4917.asp. Accessed on [2019.09.21]

17. L. Yang, X.T. He, T. Cui, D. X. Zhang, R. Zhang, M.T. Wang, IntAgri\&Biol Eng, 8(4), 1-9 (2015) doi: 10.3965/j.ijabe.20150804.1717 
18. KvernelandMonopill seed meter. Available: https:/uk.kverneland.com/KvernelandSeeding/Precision- Drills/Kverneland-Monopill-Monopill-e-drive-II. Accessed on [2019.09.21]

19. Kverneland Optima seed meter. Available: https://uk.kverneland.com/KvernelandSeeding/Precision- Drills/Kverneland-Optima-rigid . Accessed on [2019.09.21]

20. Horsch seed meter. Available: https://www.horsch.com/en/products/seedingtechnology/single-grain-seed-drills/maestro/maestro-cc/. Accessed on [2019.09.21]

21. Vaderstad seed meter. Available: https://www.vaderstad.com/en/planting/tempoplanter/tempo-r-4-6/ . Accessed on [2019.09.21]

22. Klen seed meter. Available:https://klen-agro.ru/klen-2.8s.html. Accessed on [2019.09.21]

23. Vaderstad brochure. Available: https://www.vaderstad.com/en/planting/tempoplanter/tempo-r-4-6/\#Downloads. Accessed on [2019.10.11]

24. Horsch planters' brochure. Available: https://www.horsch.com/en/service/downloads/sowing/en-english/. Accessed on [2019.10.11]

25 .

WaveVision

seed

sensor.

Available:https://www.precisionplanting.com/products/product/wavevision. Accessed on [2019.10.11]

26. Kinzeplanters manuals. Available: https://www.kinze.com/owners/productmanuals.Accessed on [2019.10.11]

27. VaderstadSeedEye technology. Available: https://www.vaderstad.com/en/drilling/rapidseed-drills/vaderstad-seedeye-for-the-farming-of-the-future/. Accessed on [2019.10.11]

28. Precision farming solutions. Available: https://ien.kverneland.com/iMFARMING/IsoMatch. Accessed on [2019.10.11]

$29 . \quad$ ISOBUS Solutions. Available: https://www.horsch.com/au/products/intelligence/isobus-solutions/. Accessed on [2019.10.11]

30. displays for Kinze planters. Available: https://www.kinze.com/blog/displays-for-kinzeplanters-options-features-and-differences. Accessed on [2019.10.11]

31. Vaderstad E-control. Available: https:/www.vaderstad.com/en/e-services/e-control/. Accessed on [2019.10.11]

32. Irtem seed control system. Available: http://www.irtem.com.tr/en/spare-part. Accessed on [2019.10.11]

33. Amazone electronics. Available: http://www.amazone.net/102.asp. Accessed on [2019.10.11]

34. Sola optional equipment. Available: https://solagrupo.com/en/ct/mechanical-optionalequipment-8?page $=3$. accessed on [2019.10.11]

35. Klen remote control. Available: https://klen-agro.ru/klen-2.8s.html. Accessed on [2019.10.11]

36. KvernelandMonopill series. Available: https://uk.kverneland.com/KvernelandSeeding/Precision-Drills/Kverneland-Monopill-Monopill-e-drive-II . Accessed on [2019.10.21]

37. Kverneland Optima series. Available: https://uk.kverneland.com/KvernelandSeeding/Precision-Drills/Kverneland-Optima-rigid. Accessed on [2019.10.21] 
38.

Horsch

Maestro

Characteristics.

Available:

https://www.horsch.com/en/products/seeding-technology/single-grain-seeddrills/maestro/maestro-cc/. Accessed on [2019.10.21]

39. Ozduman seeding group. Available: http://ozduman.com/en-US/product/seedinggroup/1056. accessed on [2019.10.21]

40. Kinze precision planters. Available: https://www.kinze.com/planters. accessed on [2019.10.21]

41. Vaderstad Tempo planter. Available: https://www.vaderstad.com/en/planting/tempoplanter/. accessed on[2019.10.21]

42. Irtem disc planter. Available: http://www.irtem.com.tr/en/disc-type. accessed on [2019.10.21]

43. Amazone precision sowing technology. Available: http://www.amazone.net/98.asp. accessed on [2019.10.21]

44. Sola precision planters' brochure. Available: https://solagrupo.com/en/docs/all. accessed on [2019.10.21]

45. Klen precision planters. Available: https://klen-agro.ru/index.html. accessed on [2019.10.21]

46.

MaterMacc precision planters.

Available:

http://www.matermacc.it/eng/seminatrici.html. accessed on [2019.10.21] 